\title{
Kajian Perencanaan Tata Ruang untuk Memfasilitasi Kegiatan Non-Pertanian di Kecamatan Sukorejo, Kabupaten Kendal
}

\author{
Ratika Tulus Wahyuhana ${ }^{1}$ \\ Magister Pembangunan Wilayah dan Kota \\ Universitas Diponegoro, Semarang, Indonesia
}

\section{Agung Sugiri}

Magister Pembangunan Wilayah dan Kota

Universitas Diponegoro, Semarang, Indonesia

Artikel Masuk : 4 Juni 2014

Artikel Diterima : 31 Juli 2014

\begin{abstract}
Abstrak: Sektor non-pertanian pedesaan merupakan sektor potensial untuk meningkatkan kesejahteraan masyarakat pedesaan, namun seringkali kurang didorong oleh kebijakan pemerintah daerah terutama dalam penyusunan perencanaan tata ruang (Sugiri et al, 2011). Kondisi tersebut terjadi di Kecamatan Sukorejo, Kendal sebagai wilayah yang memiliki potensi non-pertanian. Dengan demikian, yang menjadi Research Question adalah : "bagaimana perencanaan tata ruang dapat memfasilitasi secara lebih baik pengembangan sektor non-pertanian pedesaan di Kecamatan Sukorejo?" Penelitian ini menggunakan pendekatan kualitatif dan metode analisis deskriptif kualitatif. Hasil kajian penelitian menunjukkan kegiatan non-pertanian pedesaan di Kecamatan Sukorejo mampu menciptakan lapangan kerja bagi masyarakat. Menurut struktur ruang, belum mempertimbangkan konektivitas wilayah sebagai pendukung kegiatan. Berdasarkan pola ruang, penjabaran hanya terbatas pada zonasi. Intensitas kegiatan hanya untuk diferensiasi kegiatan berdasarkan jenis. Konstruksi masyarakat menunjukkan bahwa hasil perencanaan tata ruang kurang menguntungkan bagi masyarakat pelaku kegiatan non-pertanian. Dapat disimpulkan bahwa peran perencanaan tata ruang bersifat menghambat pengembangan kegiatan non-pertanian pedesaan di Sukorejo. Agar dapat memfasilitasi secara lebih baik, diperlukan perbaikan penyusunan perencanaan tata ruang yang mampu mengakomodasi kebutuhan masyarakat dari proses input, produksi, dan distribusi dalam aspek ruang sehingga jika dilaksanakan dengan baik dapat membantu dalam upaya pengentasan kemiskinan.
\end{abstract}

Kata kunci: Perencanaan tata ruang, pengentasan kemiskinan, kegiatan non-pertanian pedesaan, partisipasi masyarakat.

Abstract: Rural non-farm sector is potential to alleviate poverty and improve rural people's welfare; however, its development is less encouraged by the government policy, especially the regional spatial plans in Indonesia (Sugiri, et al. 2011). The situation also occurs in Sukorejo District (Kecamatan) of Kendal Regency (Kabupaten) as a potential region for developing rural non-farm sector. This study is aimed at answering the research question of: "How can spatial planning facilitate better the development of rural non-farm sector in

\footnotetext{
${ }^{1}$ Korespondensi Penulis: Magister Pembangunan Wilayah dan Kota, Fakultas Teknik, Universitas Diponegoro email : atieka.tulus@gmail.com
} 
Sukorejo District?" The approach used is qualitative with qualitative descriptive analysis method. The findings show that the rural non-farm activities in Sukorejo District are able to create siginificant jobs for the local community. However, with regard to the spatial structure, the people engaged in rural non-farm activities perceive that intra- and inter-regional connectivity has not been supporting the acitivities. As for the spatial function, they are of the opinion that the spatial plan has no benefits to offer. So, the constructs of the community show that the spatial plan does not facilitate appropriately the development of rural non-farm activities. In some aspects, especially in the spatial structure, implementation of the spatial plan can even be obstructing. It has also been found out that the planning process was not participatory at all as far as the rural non-farm people are concerned. Therefore, reformulation of the spatial planning process is needed so that the plan can accommodate the community needs in the aspects of input, production, and distribution in the rural non-farm sector. Finally, necessary measures towards the reformulation are recommended in this study.

Keywords: Spatial planning, poverty allevation, rural non-farm sector, community participation

\section{Pendahuluan}

Sektor pertanian yang menjadi dominasi mata pencaharian penduduk pedesaan telah mengalami stagnasi sehingga masyarakat miskin di pedesaan menjadi semakin tergantung pada kegiatan non-pertanian sebagai sumber penghasilan (ILO, 2004). Salah satu aspek penting yang perlu diperhatikan dalam pengembangan kegiatan non-pertanian yaitu peran perencanaan tata ruang yang seringkali belum mampu mendorong kegiatan non-pertanian pedesaan. Kecamatan Sukorejo merupakan wilayah pedesaan non-pertanian dengan karakteristik urbanisasi rendah, kedekatan dengan pusat metropolitan di Semarang, dan potensi yang baik untuk mengembangkan kegiatan produktif non-pertanian (Bappeda Jawa Tengah 2009).

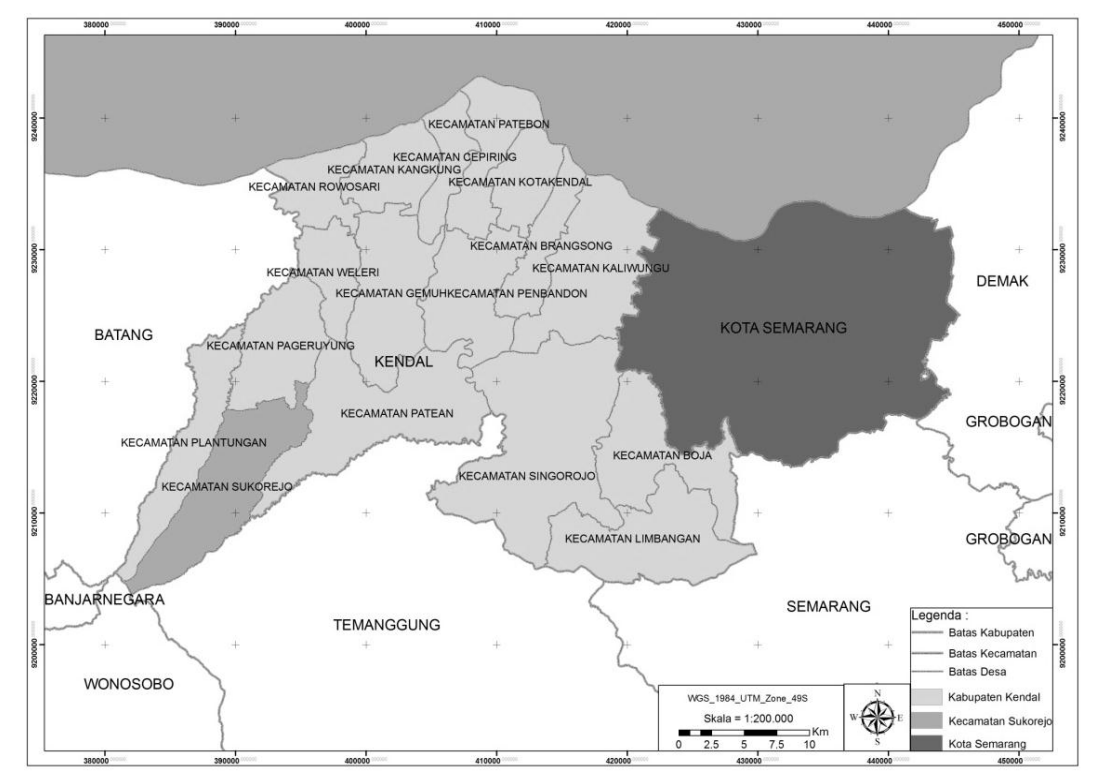

Gambar 1. Peta Orientasi Kecamatan Sukorejo 
Dalam pengembangan sektor non-pertanian pedesaan di Kecamatan Sukorejo kurang didorong oleh kebijakan pemerintah daerah terutama dalam perencanaan tata ruang. Hal tersebut dapat dilihat dalam pasal 59 huruf c dalam Perda RTRW Kabupaten Kendal mengenai ketentuan umum peraturan zonasi sistem pusat kegiatan untuk PKL dijelaskan bahwa salah satu sektor non-pertanian yang dibatasi/tidak diperbolehkan untuk dikembangkan yaitu kegiatan industri kecil hingga besar. Sedangkan dalam kondisi eksistingnya sudah berkembang berbagai industri kecil. Terjadi ketidaksesuaian antara rencana yang tertuang dalam Perda RTRW dengan kondisi eksisting sehingga diperlukan kajian untuk mengetahui bagaimana perencanaan tata ruang dapat memfasilitasi secara lebih baik kegiatan non-pertanian pedesaan di Kecamatan Sukorejo.

\section{Metode Penelitian}

Metode pendekatan yang digunakan dalam penelitian ini adalah pendekatan penelitian kualitatif (studi kasus) yaitu peran/fasilitasi perencanaan tata ruang (planning) yang dalam implementasinya dapat dilihat berdasarkan performance/kinerjanya apakah perencanaan tata ruang tersebut bersifat mendukung, menghambat, atau netral bagi pengembangan kegiatan non-pertanian pedesaan. Selanjutnya, dari kinerja tersebut dibandingkan dengan apa yang dirasakan oleh masyarakat melalui persepsi/aspirasi mereka. Teknik pengumpulan data primer terdiri dari wawancara, observasi lapangan, dan FGD dan pengumpulan data sekunder dengan studi literatur dan telaah dokumen.

\section{Gambaran Umum Kegiatan Non-Pertanian Pedesaan}

Kegiatan non-pertanian pedesaan yang terdapat di Kecamatan Sukorejo meliputi industri rumah tangga dan industri kecil, pariwisata, serta perdagangan dan jasa. Berikut potensi kegiatan non-pertanian di Kecamatan Sukorejo. Industri rumah tangga dan industri kecil yang terdapat di Kecamatan Sukorejo meliputi industri makanan dan kerajinan. Pada potensi pariwisata meliputi pariwisata alam, budaya, dan pariwisata buatan. Dari potensi perdagangan yaitu tersedianya pasar tradisional Sukorejo yang menjadi pusat perekonomian di tiga kecamatan di sekitarnya.

Tabel I Kajian Potensi Kegiatan Non-Pertanian Di Kecamatan Sukorejo

\begin{tabular}{c|l|l}
\hline No & \multicolumn{1}{|c}{ Jenis Potensi } & \multicolumn{1}{c}{ Lokasi } \\
\hline $\mathbf{1}$ & Industri Makanan dan Minuman & \\
\hline a & Tempe & Kalipakis, Kebumen, Sukorejo \\
\hline b & Kripik paru, kripik tempe, tempe bumbung & Kebumen, Sukorejo, Trimulyo \\
\hline c & Lengko-lengko (makanan camilan berbasis singkong) & Trimulyo, Kalipakis \\
\hline d & Rengginan, kue basah & Trimulyo, Pesaren \\
\hline e & Emping melinjo & Damarjati \\
\hline f & Makanan olahan Jambu & Kalibogor \\
\hline g & Air Minum dalam Kemasan & Ngadiwarno \\
\hline $\mathbf{2}$ & Industri Kerajinan & \\
\hline h & Anyaman bambu (gedhek, tudung saji, cething dll) & Ngadiwarno \\
\hline $\mathbf{3}$ & Pariwisata & \\
\hline i & Curug Terong & Gentinggunung \\
\hline j & Makam Kyai Syeban dan Petilasan Endang Sukati & Tamanrejo \\
\hline k & Air Batu Tumpuk & Tamanrejo \\
\hline $\mathbf{4}$ & Perdagangan & \\
\hline & &
\end{tabular}


Kajian Perencanaan Tata Ruang untuk Memfasilitasi Kegiatan Non-Pertanian di Kecamatan Sukorejo...

\begin{tabular}{c|l|l}
\hline No & \multicolumn{1}{|c|}{ Jenis Potensi } & \multicolumn{1}{c}{ Lokasi } \\
\hline 1 & Industri Makanan dan Minuman & \\
\hline 1 & Pasar Sukorejo & Sukorejo \\
\hline Sumbers
\end{tabular}

Sumber: Bappeda Kabupaten Kendal, 2013

\section{Kajian Pustaka: Kegiatan Non-Pertanian Pedesaan dalam Perencanaan Tata Ruang}

\section{Kegiatan non-pertanian pedesaan (Rural Non-Farm)}

Menurut Kristiansen (2003:8) definisi kegiatan non-pertanian pedesaan yaitu semua kegiatan non-pertanian di pedesaan yang menghasilkan pendapatan kecuali produksi tanaman dan ternak, menangkap ikan dan berburu, yang terletak di kawasan yang utamanya melayani kegiatan pertanian. Kegiatan non-pertanian pedesaan ini memiliki sektor yang tidak homogen dan biasanya memiliki skala yang kecil dan sering bergerak di sektor informal. Dengan demikian, kegiatan non-pertanian pedesaan dapat didefinisikan sebagai kegiatan ekonomi yang utamanya selain kegiatan primer di pedesaan yang pada umumnya berskala kecil dan memiliki keterkaitan dengan kegiatan ekonomi primer.

Bekerja di kegiatan non-pertanian pedesaan dapat memainkan peran yang berpotensi signifikan dalam meningkatkan pertumbuhan dan mengurangi kemiskinan di pedesaan (Islam 1997, Gordon 2001, Haggblade 2010, Smith 2003) yaitu mampu menyediakan kesempatan kerja, memberikan kontribusi terhadap pertumbuhan pedesaan, membantu dalam mengontrol tingkat migrasi desa-kota, mendukung pemerataan pendapatan serta memberikan kontribusi dalam pengentasan kemiskinan.

Banyak kegiatan non-pertanian pedesaan yang kurang produktif karena dibatasi oleh biaya yang tinggi akibat kurangnya dukungan infrastruktur, kesulitan dalam mengakses modal, mengakses pasar dan teknologi, regulasi lingkungan yang kompleks, serta terbatasnya akses terhadap informasi. Akibatnya, output/hasil dari kegiatan non-pertanian tersebut hanya mampu dipasarkan secara lokal sehingga kendala dari sisi permintaan membatasi pasar mereka (Deininger 2007, ILO 2004, World Bank 2006). Kualitas dan kuantitas infrastruktur merupakan faktor penentu aliran investasi dalam pengembangan kegiatan non-pertanian pedesaan serta dalam mengendalikan migrasi.

\section{Perencanaan Tata Ruang untuk Memfasilitasi Kegiatan Non-Pertanian Pedesaan}

Menurut Kamus Penataan Ruang (2010), definisi dari perencanaan tata ruang sendiri adalah suatu proses untuk menentukan struktur ruang dan pola ruang yang meliputi penyusunan dan penetapan rencana tata ruang. Struktur ruang meliputi fungsi pusat pelayanan serta sistem jaringan prasarana dan sarana yang berfungsi sebagai pendukung kegiatan sosial ekonomi masyarakat yang secara hirarkis memiliki hubungan fungsional. Sedangkan pola ruang/fungsi ruang merupakan distribusi peruntukan ruang dalam suatu wilayah yang meliputi peruntukan ruang untuk fungsi lindung dan peruntukan ruang untuk fungsi budidaya. Heterogenitas fungsi dan penggunaan lahan dari masing-masing wilayah harus membentuk jaringan antarkawasan agar terdapat kerjasama untuk pengembangan sektor dan keterkaitan spasial yang saling mendukung (Sugiri et al, 2014). Sehingga dengan demikian pengembangan kegiatan ini membutuhkan dorongan dari kebijakan spasial atau perencanaan tata ruang dalam mengakomodasi peruntukan lahan untuk pengembangan kegiatan non-pertanian pedesaan. Selain fungsi ruang, struktur ruang dalam mendukung pengembangan kegiatan non-pertanian pedesaan yang meliputi fungsi pusat pelayanan serta sistem jaringan sarana dan prasarana yang memadai juga penting untuk diakomodasi dalam perencanaan tata ruang. Memfasilitasi kegiatan non-pertanian pedesaan melalui perencanaan tata ruang menjadi penting karena kegiatan ini mendorong upaya pengentasan kemiskinan dan peningkatan kesejahteraan jangka panjang yang 
berkesinambungan. Di samping itu, perencanaan tata ruang juga menuntut adanya peran serta (keterlibatan) masyarakat pelaku kegiatan non-pertanian pedesaan dalam memfasilitasi kegiatan non-pertanian pedesaan.

\section{Tahapan Partisipasi Masyarakat dalam Penyusunan Perencanaan Tata Ruang}

Hal-hal penting yang harus dilakukan dalam setiap tahap proses perencanaan dalam upaya mereformulasi kebijakan tata ruang yang partisipatif (Sugiri, Bukhori, dan Ma'rif 2014) yaitu pada tahap awal atau persiapan, perencana harus mengidentifikasi karakteristik penting dari masyarakat setempat. Pada tahap penelitian atau survei lapangan, perencana harus dapat menyerap persepsi dan aspirasi masyarakat melalui penerapan metode lapangan yang tepat. Selanjutnya pada tahap analisis, setidaknya hasil dari tahap ini harus dikomunikasikan dengan masyarakat. Sementara itu pada tahap penyusunan rencana, para wakil masyarakat lokal yang telah terlibat dalam tahap-tahap sebelumnya dapat diikutsertakan bersama dengan pemangku kepentingan dalam tahap penyusunan rencana.

\section{Proposisi Penelitian}

Proposisi penelitian merupakan hubungan atau keterkaitan antara konsep yang satu terhadap konsep yang lain dari masalah yang ingin diteliti. Perencanaan tata ruang dapat memfasilitasi kegiatan non-pertanian pedesaan dengan baik apabila kebijakan tersebut dalam implementasinya menghasilkan fungsi dan struktur ruang yang mendukung keterlibatan mayoritas masyarakat pedesaan dalam kegiatan ekonomi yang memiliki produktivitas tinggi sehingga mampu mendorong dalam upaya pengentasan kemiskinan.

a. Dari pola ruang dalam pengembangan kegiatan non-pertanian pedesaan yaitu fungsi ruang baik fungsi lindung dan fungsi budidaya memiliki keterkaitan secara spasial dalam mendukung kegiatan non-pertanian pedesaan.

b. Dari peran struktur ruang harus mampu mendukung kegiatan tersebut yaitu meliputi fungsi pusat pelayanan serta sistem jaringan sarana prasarana dan sarana yang memadai yang secara hirarkis memiliki hubungan fungsional sehingga dapat mendorong terwujudnya integrasi dalam pengembangan kegiatan non-pertanian pedesaan.

c. Dalam penyusunan perencanaan tata ruang dalam memfasilitasi kegiatan nonpertanian pedesaan, diperlukan adanya keterlibatan masyarakat melalui pendekatan partisipatif melalui bentuk partisipasi dan keterlibatan dalam setiap tahapan proses perencanaan (tahap persiapan hingga tahap penyusunan rencana).

\section{Analisis Perencanaan Tata Ruang untuk Memfasilitasi Kegiatan Non-Pertanian Pedesaan di Kecamatan Sukorejo}

\section{Karakteristik Kegiatan Non-Pertanian Pedesaan}

Potensi kegiatan non-pertanian di Kecamatan Sukorejo terdiri dari industri rumah tangga dan industri kecil, pariwisata, serta perdagangan dan jasa. Jumlah industri rumah tangga dan industri kecil yang berkembang di Kecamatan Sukorejo yaitu 138 unit usaha (689 tenaga kerja) dan pada lapangan usaha perdagangan dengan jumlah 434 unit.

Kecamatan Sukorejo ini merupakan kawasan pertanian tanaman pangan di antaranya ubi kayu, ubi jalar, serta jambu merah sehingga berpotensi sebagai penyedia bahan baku lokal produk olahan makanan dalam proses input kegiatan non-pertanian. Bahan baku utama untuk industri makanan ringan didapatkan dari penjual langsung dari wilayah lokal penghasil tanaman pangan seperti Desa Tampingwinarno, Selokaton, 
Ngadiwarno, Peron, Damarjati, dan Desa Mulyosari dan untuk bahan baku industri olahan jambu biji diperoleh dari Desa Kalipakis, Kalibogor, dan Desa Tampingwinarno. Dengan demikian, proses kegiatan non-pertanian skala kecil di Sukorejo ini menunjukkan adanya hubungan timbal balik antara kegiatan tersebut dengan sektor primer.

Bentuk keterkaitan yang baik dengan potensi lokal menunjukkan bahwa sektor pertanian dan non-pertanian pedesaan dapat terhubung langsung melalui kaitan yang terjadi di hulu atau hilir seperti yang telah dijelaskan oleh Gordon (2001). Proses produksi kegiatan industri kecil untuk olahan makanan serta kerajinan di Kecamatan Sukorejo ini aktivitasnya bercampur dengan kawasan permukiman sehingga rumah/hunian penduduk sekaligus dimanfaatkan untuk kegiatan usaha. Terdapat salah satu industri yang tidak bercampur dengan kawasan permukiman yaitu industri air minum kemasan "Army". Dalam proses distribusi hasil kegiatan non-pertanian dari industri kecil, pemasaran makanan serta kerajinan anyaman bambu sebagian besar masih dalam lingkup lokal dan sebagian dipasarkan ke sekitar wilayah Kecamatan Sukorejo. Terkait kegiatan pariwisata pengunjungnya juga masih wisatawan lokal. Hal tersebut dikarenakan potensi industri dan pariwisata yang ada belum didukung dengan sarana dan prasarana yang memadai.

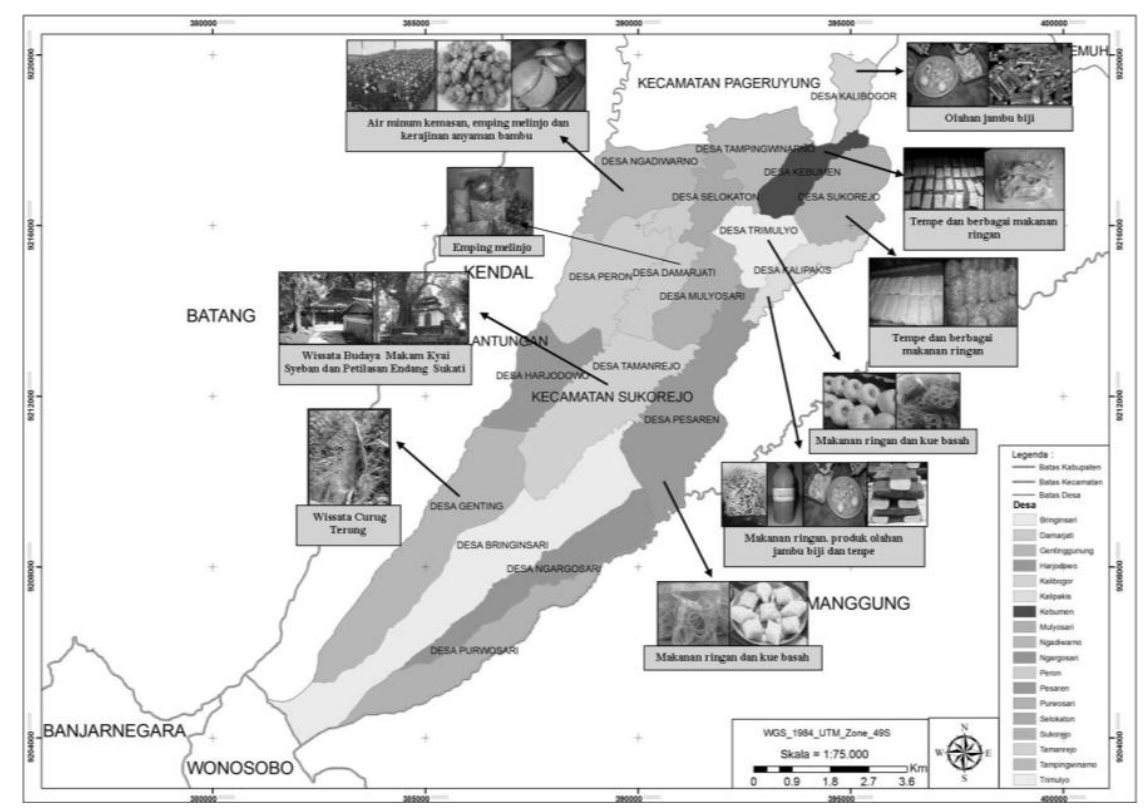

Sumber: Bappeda Kabupaten Kendal 2013 dan olahan penyusun 2014

\section{Gambar 2. Peta Potensi Kegiatan Non-Pertanian di Kecamatan Sukorejo}

\section{Penjabaran Kegiatan Non-Pertanian dalam Rencana Tata Ruang (RTRW dan RDTR) berdasarkan Struktur Ruang}

\section{Rencana Pusat Pelayanan}

Berdasarkan rencana pusat pelayanan, Kecamatan Sukorejo diklasifikasikan dalam Pusat Kegiatan Lokal (PKL) dengan kecamatan lainnya yaitu Kecamatan Kendal, Kaliwungu, Weleri, dan Boja. Meskipun hanya memiliki jangkauan pelayanan yang bersifat lokal dan level kecamatan, namun perlu adanya interaksi antar kawasan melalui pusat pengembangan sehingga heterogenitas fungsi dan penggunaan lahan dari masing-masing harus membentuk jaringan antarkawasan dan keterkaitan spasial yang saling mendukung. 
Berdasarkan pembagian BWP, Kecamatan Sukorejo dibagi dalam satu BWP (Bagian Wilayah Perkotaan) dan tiga pendukung BWP. Bagian Wilayah Kota Kecamatan Sukorejo memiliki fungsi utama sebagai pusat perdagangan jasa, pemerintahan, pelayanan umum dan permukiman yang meliputi Sub BWP I, Sub BWP II, dan Sub BWP III.

\section{Tabel II. Pembagian Wilayah Perencanaan Di Kecamatan Sukorejo}

\begin{tabular}{c|c|c}
\hline No & Sub BWP I & Pendukung BWP I \\
\hline 1 & Desa Sukorejo & $\begin{array}{c}\text { Desa Tampingwinarno, Ngadiwarno, Selokaton, Peron, } \\
\text { Damarjati, dan Desa Mulyosari }\end{array}$ \\
\hline & Sub BWP 2 & Pendukung BWP 2 \\
\hline 2 & $\begin{array}{c}\text { Desa Kebumen dan } \\
\text { Kalibagor }\end{array}$ & Desa Harjodowo, Tamanrejo, Pesaren, dan Desa Kalipakis \\
\hline 3 & Sub BWP 3 & Pendukung BWP 3 \\
\hline & Desa Trimulyo & $\begin{array}{c}\text { Sebagian Desa Ngargosari, sebagian Desa Bringinsari, Desa } \\
\text { Purwosari, dan sebagian Desa Gentinggunung }\end{array}$ \\
\hline
\end{tabular}

Sumber : RDTR Kecamatan Sukorejo 2014-2034, 2014

Desa pendukung BWP I memiliki fungsi utama hortikultura, peternakan, pelayanan umum dan permukiman. Desa pendukung BWP II dengan fungsi utama perkebunan, sempadan mata air, pariwisata dan permukiman. Desa pendukung BWP III dengan fungsi utama sebagai kawasan konservasi. Fungsi kawasan seperti pusat kegiatan perdagangan dan pariwisata, hortikultura, memiliki potensi untuk pengembangan kegiatan non-pertanian pedesaan.

\section{Sistem Jaringan Prasarana}

Sistem jaringan prasarana untuk transportasi darat di Kecamatan Sukorejo termasuk pada jalan arteri sekunder, jalan kolektor dan jalan lokal. Aksesibilitas antarwilayah Kecamatan Sukorejo masih belum memadai.
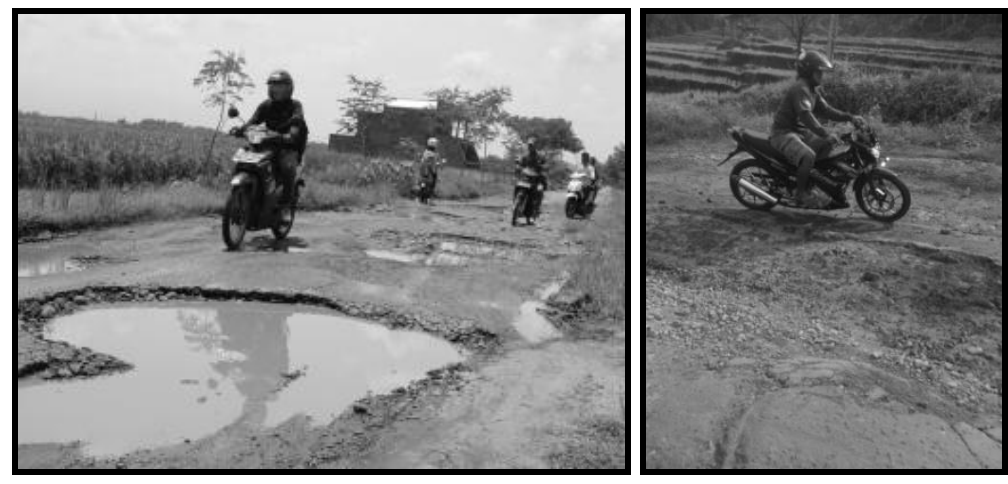

\section{Gambar 3. Kondisi Jalan Kecamatan Sukorejo}

Masih banyak jalan yang kondisinya rusak, dengan kondisi topografis yang berbukit sehingga konektivitas antarwilayah masih belum mampu mendukung secara optimal seperti akses menuju Desa Gentinggunung serta belum adanya akses menuju wilayah selatan (Kab. Banjarnegara \& Wonosobo). Dengan demikian, maka dapat menghambat kegiatan non-pertanian baik aliran bahan baku dan pemasaran. 
Sebagai upaya untuk meningkatkan aksesibilitas di Kecamatan Sukorejo yang tercantum dalam RTRW Kabupaten Kendal tahun 2011-2031, pengembangan rencana jaringan transportasi darat meliputi rencana pengembangan jaringan kolektor sekunder yang menghubungkan pada ruas jalan Bawang-Sukorejo-Patean-Singorojo-Boja-Semarang serta rencana dimensi jalan yaitu garis sempadan bangunan yang harus dalam jarak 20 meter dari as jalan untuk bangunan yang terletak di sisi jalan kolektor primer di Kecamatan Sukorejo (Jalan Raya Parakan-Sukorejo). Rencana dimensi jalan tersebut mengacu pada Perda Provinsi Jawa Tengah Nomor 11 Tahun 2004 mengenai Peraturan Garis Sempadan yang disesuaikan dengan kondisi eksisting dan Undang-Undang Tentang Jalan.
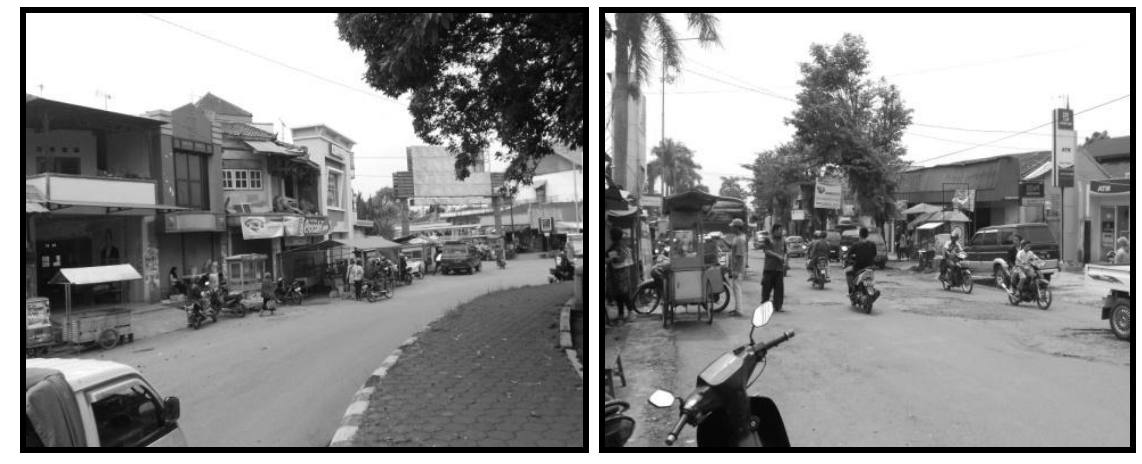

\section{Gambar 4. Kondisi Jalan Kolektor di Kecamatan Sukorejo}

Jika dilihat pada kondisi eksistingnya, persil lahan di sisi jalan utama tersebut tidak cukup besar dan bangunan di sekitar jalan utama tersebut kebanyakan juga digunakan untuk usaha. Jika rencana ini diterapkan akan menghambat pengembangan kegiatan nonpertanian.Terkait sistem prasarana lainnya, pelayanan prasarana jaringan telekomunikasi dan pengelolaan air limbah belum memadai. Kendala dalam rencana pengembangan sistem jaringan telekomunikasi yaitu kesulitan diadakan penambahan jaringan telepon pada daerah topografi curam. Terkait pengelolaan limbah, belum terdapat sistem jaringan penyaluran air limbah perpipaan padahal sudah berkembang berbagai industri di kecamatan ini. Kondisi tersebut tentunya akan berpengaruh pada perkembangan kegiatan non-pertanian pedesaan.

\section{Penjabaran Kegiatan Non-Pertanian dalam Rencana Tata Ruang Kabupaten Kendal}

\section{Rencana Pola Ruang Kawasan Lindung}

Dalam pengembangan sektor non-pertanian pedesaan sebagai kawasan budidaya tidak boleh bertentangan dengan deliniasi kawasan lindung yang telah ditetapkan dalam RTRW Kabupaten Kendal. Kecamatan Sukorejo berfungsi sebagai kawasan lindung, yaitu kawasan hutan lindung, kawasan yang memberikan perlindungan terhadap kawasan bawahannya, serta kawasan perlindungan setempat. Pengelolaan yang dilakukan pada kawasan hutan lindung terkait kegiatan non-pertanian yaitu kegiatan pariwisata yang diperkenankan adalah yang bersifat menikmati pemandangan saja seperti wisata alam Curug Terong di Desa Gentinggunung.

\section{Rencana Pola Ruang Kawasan Budidaya}

Berdasarkan RTRW Kabupaten Kendal, kawasan budidaya yang di Kecamatan Sukorejo terdiri dari hutan produksi, kawasan hortikultura dan perkebunan, kawasan tanaman pangan, kawasan tanaman tahunan, dan permukiman. 
Kaitannya dengan kegiatan non-pertanian, kawasan hutan produksi berfungsi untuk menghasilkan hasil hutan untuk industri. Kawasan hortikultura dapat dikembangkan untuk kegiatan agroindustri dan agrowisata. Kawasan tanaman perkebunan yaitu menghasilkan bahan pangan dan bahan baku industri serta pengembangan agrowisata. Pada kawasan pertanian, pembangunan yang bersifat non-pertanian tidak diperbolehkan menggunakan areal pertanian yang subur. Pada kawasan permukiman, kegiatan non-pertanian yang diatur yaitu kegiatan industri rumah tangga diperbolehkan untuk dikembangkan dan bercampur di kawasan perumahan dengan izin bersyarat (tidak menimbulkan dampak lingkungan, dll).

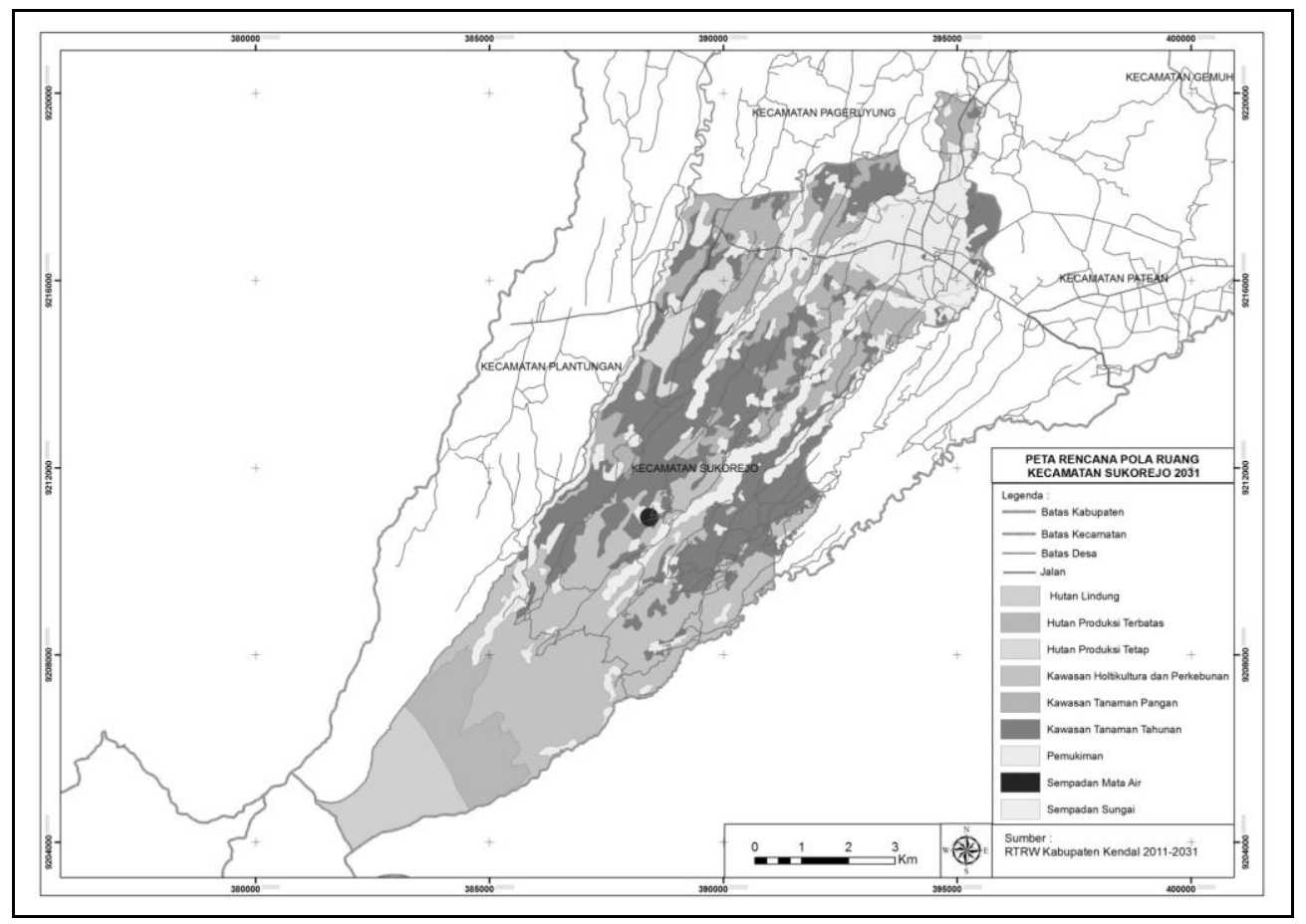

Sumber: RTRW Kabupaten Kendal Tahun 2011-2031 (Olahan)

Gambar 5. Peta Rencana dan Pola Ruang Kecamatan Sukorejo Tahun 2031

Berdasarkan RTRW dan RDTR Kecamatan Sukorejo, kegiatan industri yang diperbolehkan yaitu industri skala rumah tangga yang proses produksinya bercampur dengan kawasan permukiman dengan izin bersyarat. Terkait dengan sektor industri, terdapat salah satu bentuk penyimpangan pemanfaatan ruang yaitu keberadaan industri air minum kemasan Army di Desa Ngadiwarno. Industri tersebut terletak di kawasan pertanian yang dapat dilihat pada peta rencana pola ruang RDTR Kecamatan Sukorejo.

Dalam peraturan zonasi pemanfaatan ruang untuk kawasan pertanian, tidak diperbolehkan untuk dikembangkan segala jenis kegiatan industri baik rumah tangga, kecil hingga besar. Disinsentif untuk penggunaan lahan berupa industri hanya dijelaskan dalam RTRW dan tidak dijabarkan lebih lanjut dalam RDTR. Penertiban terhadap pemanfaatan ruang yang tidak sesuai dengan rencana tata ruang yaitu dalam bentuk pengenaan sanksi dengan peraturan perundang-undangan yang berlaku, baik sanksi administratif, pidana, maupun perdata. Dengan demikian, rencana yang tertuang mengenai kegiatan industri yang dijabarkan dalam rencana tata ruang tersebut hanya memuat mengenai diferensiasi kegiatan industri berdasarkan jenis industri saja. Arahan terkait dengan insentif dan disinsentif seperti kegiatan industri merupakan aspek penting yang perlu diperhatikan. 
Insentif dan disinsentif tersebut diperuntukkan bagi masyarakat yang telah melaksanakan pemanfaatan ruang yang mendukung dan tidak mendukung terwujudnya arahan dalam RTRW Kabupaten Kendal. Industri tersebut juga tidak berkontribusi terhadap masyarakat lokal karena tenaga kerjanya mayoritas dari luar wilayah. Masalah yang terjadi pada saat pembangunan industri tersebut yaitu tidak terdapat perjanjian awal/MOU antara pihak industri dengan pihak desa. Pada saat pembangunan hingga saat ini, kondisi jalan lingkungan di sekitarnya menjadi rusak.

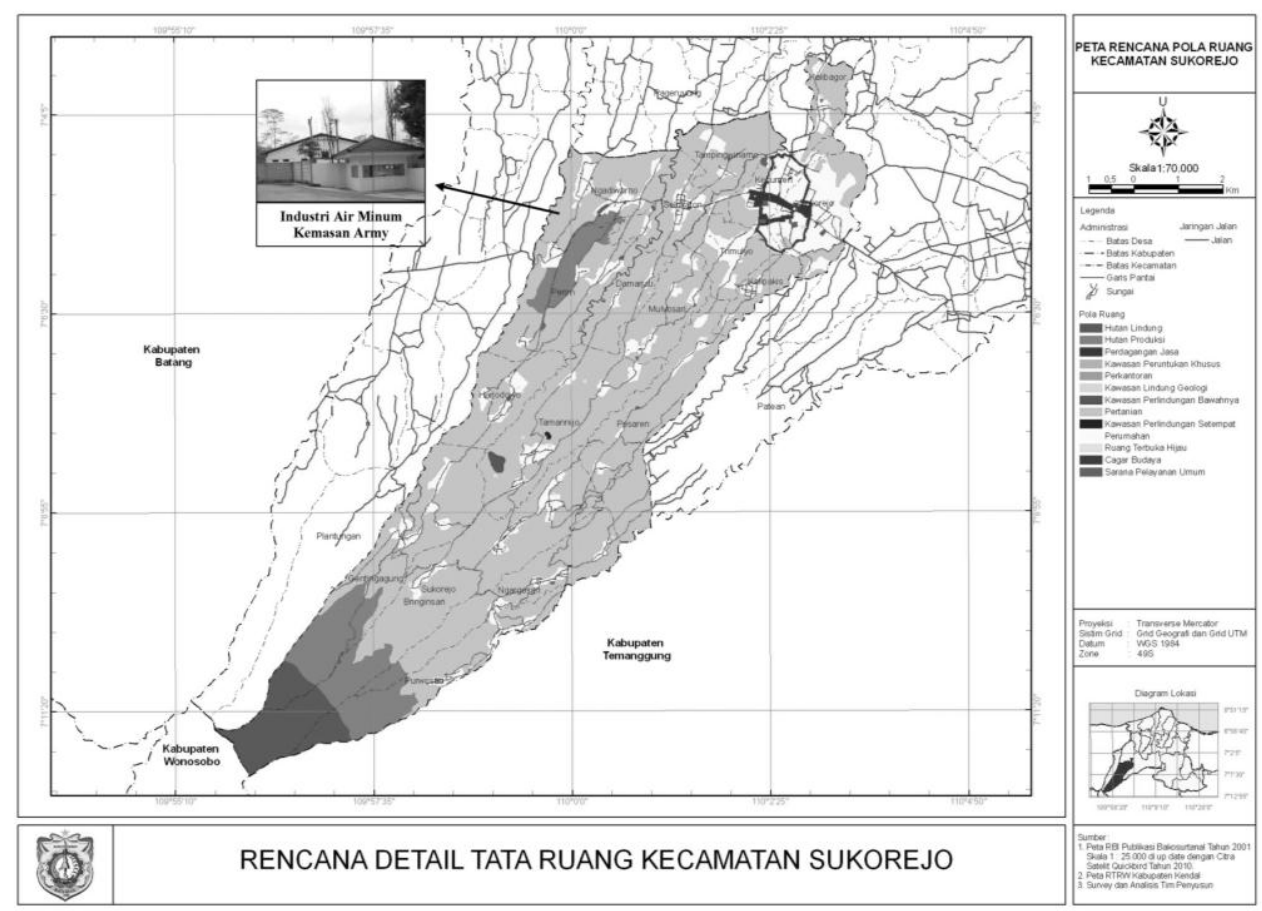

Sumber: RDTR Kecamatan Sukorejo 2014-2034 (Olahan)

Gambar 6. Peta Lokasi Industri Air Minum Kemasan menurut RDTR Kecamatan Sukorejo

Berdasarkan RTRW Kabupaten Kendal, Kecamatan Sukorejo termasuk ke dalam wilayah pengembangan pariwisata. Potensi pariwisata dapat dilihat pada tabel berikut:

Tabel 3. Potensi Pengembangan Pariwisata Sukorejo menurut Rencana Tata Ruang

\begin{tabular}{c|l|c|c}
\hline No & RTRW Kabupaten Kendal & RDTR Kecamatan Sukorejo & Lokasi (Desa) \\
\hline $\mathbf{1}$ & Pariwisata Alam & Curug Terong & \\
\hline a & Curug Terong & Air Batu Tumpuk & Gentinggunung \\
\hline b & Tidak ada & & Tamanrejo \\
\hline $\mathbf{2}$ & Pariwisata Religi & $\begin{array}{l}\text { Makam Kyai Syeban \& Petilasan Endang } \\
\text { Sukati }\end{array}$ & Tamanrejo \\
\hline c & Tidak ada & & \\
\hline $\mathbf{2}$ & Pariwisata Buatan & Tidak ada & Banaran \\
\hline d & Kebun Cengkeh Banaran & Tidak ada & Ngadiwarno \\
\hline e & Agrowisata Ngadiwarno & & \\
\hline
\end{tabular}

Sumber : RTRW Kabupaten Kendal dan RDTR Kecamatan Sukorejo, 2014

Dalam RTRW Kabupaten Kendal 2011-2031, Kecamatan Sukorejo direncanakan sebagai pengembangan pariwisata buatan yaitu agrowisata Ngadiwarno yang berlokasi di 
desa Ngadiwarno. Namun rencana pengembangan agrowisata ini tidak tercantum dalam RDTR sehingga terjadi ketidaksesuaian. Dengan demikian, arahan terkait pengembangan kegiatan pariwisata menunjukkan bahwa perencanaaan tata ruang belum mampu mendorong kegiatan non-pertanian ini secara maksimal.

\section{Konstruksi Masyarakat Sukorejo dalam Penyusunan Rencana Tata Ruang Kab. Kendal Peran/Fasilitasi Fungsi Ruang dan Struktur Ruang}

Berkaitan dengan rencana tata ruang (RTRW Kabupaten Kendal dan RDTR Kecamatan Sukorejo), secara umum masyarakat Sukorejo pelaku usaha kegiatan nonpertanian menganggap hal tersebut penting yaitu dapat mengarahkan dan mendorong pembangunan dalam aspek keruangan. Masyarakat menganggap bahwa dalam rencana tata ruang tersebut tidak selalu bermanfaat bagi mereka. Mereka menyayangkan terkait penentuan garis sempadan bangunan yang harus berada dalam jarak 20 meter dari as jalan untuk bangunan yang terletak di sisi jalan kolektor primer sebagai hal yang merugikan. Jika rencana tersebut diterapkan, maka akan banyak masyarakat yang kekurangan lahan untuk hunian maupun usaha mereka. Arahan terkait industri juga dianggap tidak konsisten bagi masyarakat Sukorejo. Arahan tersebut hanya menyebutkan mengenai jenis industri yang diperbolehkan yaitu industri skala rumah tangga yang aktivitasnya bercampur dengan kawasan permukiman. Namun, tidak ada penjabaran secara spasial terkait industri lainnya yang sudah tidak bercampur dengan kawasan permukiman.

Terkait rencana pengembangan agrowisata Ngadiwarno yang tercantum di RTRW Kabupaten Kendal, secara umum seluruh peserta FGD setuju terhadap rencana tersebut. Mereka menginginkan adanya penjabaran lebih lanjut mengenai potensi yang ada dan penjabaran konsepnya, tidak hanya disebutkan saja.
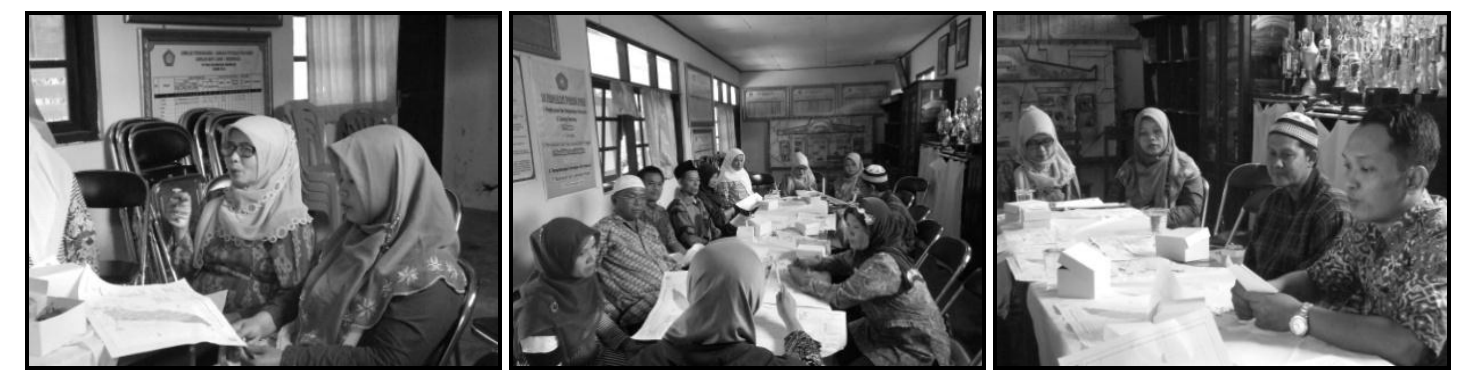

\section{Gambar 7. Suasana Diskusi pada saat FGD di Kecamatan Sukorejo}

Dari persepsi seluruh peserta FGD, maka dapat disimpulkan bahwa rencana tata ruang selama ini yaitu RTRW Kabupaten Kendal dan RDTR Kecamatan Sukorejo bersifat menghambat pengembangan kegiatan non-pertanian yang selama ini melibatkan masyarakat banyak di Kecamatan Sukorejo. Seluruh peserta FGD mengungkapkan bahwa rencana tata ruang tersebut masih belum menguntungkan dan konsisten dalam memberikan arahan pembangunan di Kecamatan Sukorejo.

\section{Bentuk dan Tingkat Partisipasi Masyarakat}

Masyarakat menyadari bahwa perwakilan masyarakat yang terlibat dalam perencanaan tata ruang bukan dari perwakilan mereka. Perwakilan masyarakat yang dilibatkan yaitu kepala desa, tokoh masyarakat, dan tokoh agama. Perwakilan tersebut hanya dilibatkan pada saat penjaringan aspirasi, sosialisasi rancangan rencana, serta penyampaian rancangan perda dan rencana. Berdasarkan tingkat partisipasi masyarakat 
Sukorejo, berada pada tingkat keempat yaitu tingkat Consultation (delapan tangga partisipasi Arnstein) dan berada dalam derajad tokenisme yaitu suatu tingkat partisipasi di mana masyarakat didengar dan diperkenankan berpendapat, tetapi tidak memiliki jaminan bahwa pandangan mereka akan dipertimbangkan.

Tabel 4. Pelaku yang Berperan dalam Proses Penyusunan RDTR di Kecamatan Sukorejo

\begin{tabular}{|c|c|c|c|c|}
\hline \multirow{2}{*}{ No } & \multirow{2}{*}{ Kegiatan } & \multicolumn{3}{|c|}{ Pelaku } \\
\hline & & Pemerintah & Masy. & Konsultan \\
\hline $\mathbf{A}$ & Tahap I: Persiapan & & & \\
\hline 1 & Pengumuman & $\mathrm{x}$ & - & - \\
\hline 2 & Pembentukan tim teknis & $\mathrm{x}$ & - & - \\
\hline B & Tahap II: Penyusunan Rencana & & & \\
\hline 3 & Penyusunan Laporan Pendahuluan & - & - & $\mathrm{x}$ \\
\hline 4 & Pembahasan Laporan Pendahuluan & $\mathrm{x}$ & - & $\mathrm{x}$ \\
\hline 5 & Survei instansional dan lapangan & - & - & $\mathrm{x}$ \\
\hline 6 & Penjaringan Aspirasi Masyarakat & $\mathrm{x}$ & $\mathrm{x}$ & $\mathrm{x}$ \\
\hline 7 & $\begin{array}{l}\text { Penyusunan Laporan Kompilasi dan Analisa Data (Laporan } \\
\text { Antara) }\end{array}$ & - & - & $\mathrm{x}$ \\
\hline 8 & $\begin{array}{l}\text { Pembahasan Laporan Kompilasi dan Analisa Data (Laporan } \\
\text { Antara) }\end{array}$ & $\mathrm{x}$ & - & $\mathrm{x}$ \\
\hline 9 & Penyusunan Draft Rencana & - & - & $\mathrm{x}$ \\
\hline 10 & Pembahasan Laporan Draft Rencana & $\mathrm{x}$ & - & $\mathrm{x}$ \\
\hline 11 & Seminar/Lokakarya Rancangan Rencana & $\mathrm{x}$ & - & $\mathrm{x}$ \\
\hline 12 & Sosialisasi Rancangan Rencana & $\mathrm{x}$ & $\mathrm{x}$ & $\mathrm{x}$ \\
\hline 13 & Penyempurnaan rancangan rencana menjadi Rencana & $\mathrm{x}$ & - & $\mathrm{x}$ \\
\hline $\mathbf{C}$ & Tahap III: Penetapan Rencana & & & \\
\hline 14 & Penyiapan Rancangan Peraturan Daerah & $\mathrm{x}$ & - & - \\
\hline 15 & Penyampaian Rancangan Perda dan Rencana & $\mathrm{X}$ & $\mathrm{X}$ & - \\
\hline
\end{tabular}

\section{Tahapan Perencanaan dalam Penyusunan Rencana Tata Ruang}

Pada saat dikonfirmasi pendapat mengenai bagaimana partisipasi masyarakat harus dilakukan dalam proses penyusunan rencana tata ruang, mereka setuju pada beberapa prinsip penting.

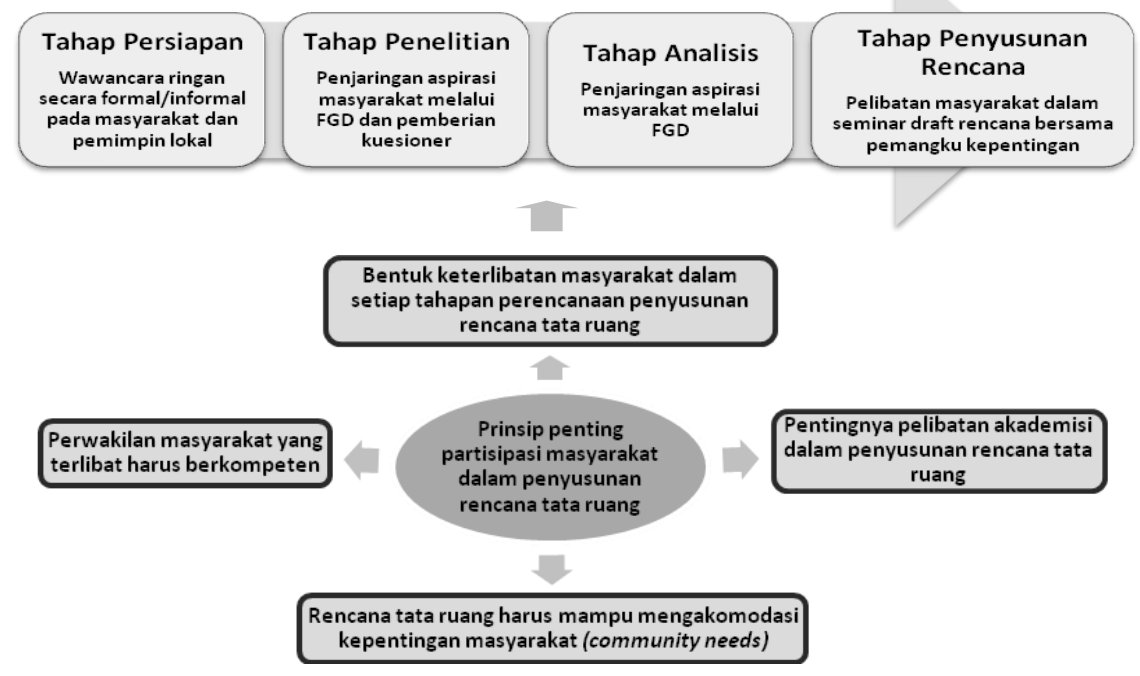




\section{Gambar 8. Prinsip Penting Partisipasi Masyarakat dalam Penyusunan Rencana Tata Ruang}

Yang pertama yaitu mereka yang terlibat dalam partisipasi proses perencanaan tata ruang harus benar-benar mewakili masyarakat dan memiliki kompetensi dalam memahami kebutuhan masyarakat Sukorejo. Prinsip kedua, rencana tata ruang harus mampu mengakomodasi kepentingan mereka (community needs). Prinsip ketiga yaitu keterlibatan masyarakat dalam setiap tahapan proses perencanaan dalam penyusunan rencana tata ruang yaitu meliputi tahap awal/persiapan, hingga penyusunan rencana.

Dengan memenuhi prinsip-prinsip tersebut maka aspirasi masyarakat dapat terakomodasi dengan baik dalam perencanaan tata ruang terkait kegiatan non-pertanian pedesaan sehingga mampu mendorong dalam upaya pengentasan kemiskinan.

\section{Kesimpulan}

Berdasarkan karakteristik kegiatan non-pertanian pedesaan di Kecamatan Sukorejo, sektor tersebut telah mampu menciptakan lapangan pekerjaan bagi masyarakat setempat. Proses kegiatan non-pertanian skala kecil tersebut juga menunjukkan adanya hubungan timbal balik antara kegiatan tersebut dengan sektor primer.

Dari peran rencana tata ruang (RTRW Kabupaten Kendal dan RDTR Kecamatan Sukorejo) dalam memfasilitasi kegiatan non-pertanian pedesaan menurut struktur ruang hanya menjelaskan jangkauan pelayanan berdasarkan fungsi pelayanan kawasan. Konektivitas wilayah sebagai pendukung dalam pengembangan kegiatan ini belum dipertimbangkan. Kondisi infrastruktur di Kecamatan Sukorejo masih belum memadai dan belum mampu membentuk keterkaitan spasial yang mampu mendukung kegiatan nonpertanian. Selanjutnya, dalam peran rencana tata ruang untuk memfasilitasi kegiatan nonpertanian pedesaan menurut pola ruang hanya menjabarkan zonasi kawasan lindung dan budidaya. Intensitas kegiatan terutama di kawasan budidaya tidak dijabarkan. Intensitas kegiatan non-pertanian dalam skala besar dan kecil dalam rencana tata ruang tersebut hanya untuk diferensiasi berdasarkan jenisnya saja seperti industri dan pariwisata.

Dari konstruksi masyarakat Sukorejo menunjukkan bahwa rencana tata ruang tersebut bersifat menghambat pengembangan kegiatan non-pertanian. Rencana tata ruang tersebut masih belum menguntungkan dalam memberikan arahan pembangunan di Kecamatan Sukorejo terkait pengembangan kegiatan non-pertanian skala kecil yang telah memberikan kontribusi positif dalam pengentasan kemiskinan. Masyarakat setuju pada 4 prinsip penting mengenai bagaimana partisipasi masyarakat harus dilakukan dalam proses perencanaan tata ruang yaitu mereka yang terlibat dalam partisipasi harus benar-benar mewakili masyarakat, mampu mengakomodasi community needs, keterlibatan masyarakat dalam setiap tahapan perencanaan tata ruang meliputi tahap awal/persiapan hingga penyusunan rencana serta pentingnya peranan lembaga pendidikan tinggi/akademisi dalam proses partisipasi ini. Dengan demikian, maka dapat disimpulkan bahwa RTRW Kabupaten Kendal dan RDTR Kecamatan Sukorejo 2031 bersifat menghambat bagi pengembangan kegiatan non-pertanian di Kecamatan Sukorejo. Agar dapat memfasilitasi secara lebih baik, diperlukan perbaikan penyusunan perencanaan tata ruang yang mampu mengakomodasi kebutuhan masyarakat yang lebih sesuai dan lebih mendukung kegiatan non-pertanian yaitu dikaji dari proses input, produksi, dan distribusi dalam aspek ruang sehingga jika dilaksanakan dengan baik dapat membantu dalam upaya pengentasan kemiskinan. 


\section{Kajian Perencanaan Tata Ruang untuk Memfasilitasi Kegiatan Non-Pertanian di Kecamatan Sukorejo...}

\section{Daftar Pustaka}

Bappeda Jawa Tengah. 2009. Rencana Tata Ruang Wilayah (RTRW) Provinsi Jawa Tengah 2009-2029. Semarang: Bappeda Jawa Tengah.

Bappeda Kabupaten Kendal. 2013. Laporan Akhir: Kajian Potensi Kecamatan Sukorejo. Kendal: Bappeda Kabupaten Kendal.

Bappeda Kabupaten Kendal. 2014. Rencana Tata Ruang Wilayah (RTRW) Kabupaten Kendal 2011-2031. Kendal: Bappeda Kabupaten Kendal.

2014. Rencana Detail Tata Ruang Kota (RDTRK) Kecamatan Sukorejo 2014-2034. Kendal: Bappeda Kabupaten Kendal.

Deininger, K., S. Jin and M. Sur. 2007. Sri Lanka's Rural Non-Farm Economy: Removing Constraints to ProPoor Growth. The International Journal of World Development, Vol 35, No. 12, pp.2056-2708.

Gordon, Ann and Craig, Catherine. 2001. Rural Non-farm Activities and Poverty Allevation in Sub-Saharan Africa. Policy Series 14. Chatham, UK: Natural Resources Institute.

Haggblade, S., P. Hazell and T. Reardon. 2010. The Rural Non-farm Economy: Prospects for Growth and Poverty Reduction. The International Journal of World Development, Vol 38 (10), 1429-1441.

ILO. 2004. Pembangunan Pedesaan: Akses, Ketenagakerjaan dan Peluang Meraih Pendapatan (Rural Development: Access, Employment and Income Opportunities). Jakarta: ILO.

Islam, Nurul.1997. The Nonfarm Sector and Rural Development (Review of Issues and Evidence). International Journal Policy Research Institute. Washington.

Kamus Penataan Ruang Edisi 2. 2010. Direktorat Jenderal Penataan Ruang Departemen Pekerjaan Umum.

Kristiansen, S. 2003. Linkages and Rural Non-Farm Employment Creation: Changing Challenges and Policies in Indonesia, ESA Working Paper No. 03-22, FAO.

Smith, David Rider. 2003. The Spatial Dimension of the Non-Farm Economy in Uganda. Journal of Natural Resources Institute No 2673.

Sugiri, A., I. Buchori and S. Ma'rif. 2014. Towards Participatory Spatial Policy : Facilitating Rural Non-farm Activities in Susukan Suburb of Semarang Metropolitan Region, The International Journal of Civic, Political and Community Studies, Vol 12, 2014, Forthcoming.

World Bank. 2006. Revitalizing the Rural Economy: An assessment of the investment climate faced by nonfarm enterprises at the District level. Washington D.C : World Bank. 